\title{
Community Relations as Main Strategy in Building Positive Corporate Reputation \& Sustainability: The Case of PT Saung Angklung Udjo in Bandung, West Java, Indonesia
}

\author{
Kevin Lineria \\ Department of Communication Studies \\ University of Indonesia \\ Jakarta, Indonesia \\ kevin.lineria@gmail.com
}

\begin{abstract}
This research is focusing on the concept of community relations which mostly known as CSR and also one kind of relationship that is carried out by corporate public relations practitioners. In this study, the researcher took on a fairly unique case of a cultural tourism company that focuses on the preservation of angklung as Indonesia traditional music, PT Saung Angklung Udjo (SAU) which located in Bandung, West Java, Indonesia. The purpose of this study is to explore and explain how PT Saung Angklung Udjo uses community relations as their main strategy to obtain a positive corporate reputation in the eyes of their stakeholders. The approach used in this study is qualitative. First, this research conducted an indepth interview with 8 key informants who were directly or indirectly involved in PT SAU's decision to use community relations as their main strategy. Secondly, the researcher conducted observations in PT SAU for several months from July 2018 to June 2019. Using a thematic data analysis method, the study finds that community relations is internalized as a core corporate value and implemented as the basis for the whole business line of PT SAU. The study also finds that the community relations concept used as the main strategy of PT SAU has succeeded to shape a positive corporate reputation in the eyes of its stakeholders. Moreover, those strategies also significantly give a real benefit to the stakeholders and as a result, it gives sustainability of PT SAU which is proven by their existence for 53 years since 1966 until now.
\end{abstract}

Keywords-Community Relations, Corporate Reputation, Corporate Sustainability, Saung Angklung Udjo, Cultural Tourism Company

\section{INTRODUCTION}

Since traditional arts and culture were introduced and became the industry also one of the bases of tourism to the people of Indonesia decades ago, many cultural groups, studios or communities have emerged in Indonesia. But, almost all of those groups can't survive without funding from the government, so one by one collapsed over time.

However, there is a cultural group in Padasuka Street, Bandung, West Java, Indonesia called Saung Angklung Udjo (SAU), which was founded by the late Udjo Ngalagena 52 years ago. In the beginning, Udjo simply made a small group of children nearby his house to preserve the traditional musical instrument of Sundanese culture called angklung. He only wants to teach the young generation about the valuable cultural heritage.

But Udjo never expected that Saung Angklung Udjo becoming the biggest and most well-known traditional arts group in Indonesia now. SAU also considered as the number one cultural tourism destinations of West Java which is proven by the high number of tourist visits. They always receives more than 1,500 tourist every day, both locals and foreigners from various countries. Each day, SAU holds three angklung performances involving more than 200 artists. Currently, SAU has more than 100 employees, 200 angklung craftsmen, 500 students, and 200 professional artists. In 1968, SAU located in the home of the Udjo's family with an area only 100 square meters. Nowadays, SAU had widened the area to 1.5 hectares, and becoming the one stop tourism destination, which is not just the place to learn angklung, but also becoming the center for Sundanese cultural development in Indonesia.

The success achieved by SAU is not without challenges and obstacles. Since it was first established, SAU received a lot of criticism from people around it, because of the noise from angklung performances that were considered disturbing the neighborhood. At that time, most of the people did not care about Indonesian traditional culture, compare to foreign music which considered more interesting. The government also has not paid much attention and provided funding for the cultural community in that era.

Researcher sees that the concept of community relations is implemented as corporate's main values and strategies. They use community relations not only for establishing mutually beneficial relations between the company and communities who lived nearby, but also to all related key stakeholders who have an influence in developing SAU's business, such as bamboo farmers, government, private sectors, and non-profit organizations. At this moment, community relations as the main strategy which is not commonly done in the business world, becoming an interesting phenomenon and new approach to be able to explain the process of achieving a positive reputation and 
sustainability of SAU for 52 years as a cultural tourism based company. An unusual business strategy pattern in the middle of skepticism and various debates about implementing CSR which considered just a waste of budget and not beneficial for the company.

\section{LITERATURE REVIEW}

\section{A. Community Relations}

Reference [1] states that the concept of community in the context of public relations has changed a lot. Community, as explained by Hartono, means the spatial units or political units of social organizations that can give individuals a sense of togetherness or a sense of belonging to one another. Still in the same book, sociologically the community has three characteristics which include the unity of the locality, social networks, and relationship-communion. One principle that will be developed through community relations is developing good neighbor relationships. Whereas, Stewart E. Perry in CED Definitions and Terminology (2001) sees two meanings of community. First, community as a category refers to people who are interconnected based on specific shared values and interests. Second, it specifically refers to one category of people who are related to one another based on the same specific locality.

1) The Role of Community for Organizational Success

A good neighbor certainly plays a role in supporting success. Communities that live around the location of the organization's operations will also support the success of an organization to achieve the goals. Moreover, Peak in Lesly (1991:117) states that it is not only those within the organization that determines the success of achieving goals, but also the communities that surround the area of the organization's operations. Community relations can be regarded as a good relationship between corporate and the surrounding environment to gain trust, mutual understanding, and support. Community relations not only covers the narrow community in the area where the company stands but can also include the wider community. Community relations is different from philanthropy and consists of only a few short-term projects, but community relations must be strategic and sustainable activities.

\section{2) Advantage of Community Relations}

Changes in organizational practices and social pressures in conducting business and showing social responsibility actually give a number of benefits for both parties. The practice of community relations focused on philanthropic activities had previously been seen to only benefit the community and to the organization was seen as a cost burden. There was no view at the time that helping the community was an important investment for the organization because business organizations as an organism must necessarily relate to the surrounding environment.

Community relations built on the vision of the company and corporate social responsibility can indeed be beneficial by both parties. This is in line with the principle of mutual benefit, which was developed through various PR programs and activities. Therefore, it is important to realize that community relations programs are not programs from companies for the community, but programs for companies and communities. Corporate social responsibility itself is carried out by business organizations basically to maintain its sustainability. [2]

\section{B. Corporate Reputation}

Reputation is a collection of beliefs and feelings of a person towards an organization [3]. Meanwhile, according to Fombrun (1996), reputation is the overall evaluation of organizational achievements. The reputation measurement indicates the level of the company in the eyes of external stakeholders based on a combination of evaluations of different images that refer to the company's activities in finance, human resources, social responsibility, and product quality.

The company's reputation provides a competitive advantage for the company. Argenti and Forman (68: 2002) state that the three main contributors to the reputation of an organization are the formed identity, the overall image formed by the public, the harmony between organizational identity and the image held by organizational constituents. Meanwhile, according to Grahame Dowling, there are three main factors affecting the reputation of the company, namely corporate identity, corporate image, \& factors of experience and assessment of the organization.

\section{1) Establishing Reputation in the Eyes of Stakeholders}

In managing a company's reputation, the first thing to consider is recognizing the company's stakeholders and then measure the company's reputation by seeing how much their awareness of the company. The next step is to develop a framework for identifying factors that affect the company's reputation. These factors can consist of what people say about our company and what the organization does to strengthen its reputation.

While the factors that influence the reputation of the customer towards the company are company policy, service quality, brand image, industrial image, competitor's image, publicity and marketing communication activities, as well as the results of communication and exchange of experience with other customers. Furthermore, to understand reputation is first examined by the principles of reputation that are reviewed in a diverse approach and emphasizes aspects of multiple stakeholder perspective (Davies, 2003: 58). It can be seen in Fombrun's (1998) article about The Stakeholder Perspective, in this principle, there needs to be an understanding of priorities in mapping the needs of each stakeholder at once. Each stakeholder has different standards, needs, and satisfaction. If reviewed in corporate reputation management, it is the same as how organizations should approach each stakeholder's perception of reputation and also set the scope for use in managing the business as a whole, which includes:

- Trustworthiness (employee's point of view): pride, empowerment

- Credibility (investor's point of view): profit, growth

- Product reliability (consumer point of view): promotion of quality, service, supporting consumers

- Responsibility (community point of view): the responsibility to the community around the company, community services and supporting a green environment 


\section{RESEARCH METHODOLOGY}

The paradigm used in this study is the social constructivism or interpretivism paradigm. This paradigm shows the unique experiences of each individual that researcher use to see, explore, and understand deeper the formulation of community relations as the main strategy in shaping the Saung Angklung Udjo's reputation, so that the formulation can become a new alternative that also modify existing theories.

This research uses a qualitative approach, which is an inductive approach. Researcher choose the type of explanatory research that aims to explain how a social phenomenon occurs. This research emphasizes on a case and conducted at a certain time interval, starting in September 2018 to August 2019. The strategy used in this research is case study. Case studies are strategies in which researcher carefully investigate a program, event, activity, process of a group or individuals, without forgetting the context behind them. However, the research does not intend to generalize or prove some theories, but focusing more to elaborate the findings in depth (Creswell, 2010: 20).

The method used for the data collection process in this study is in-depth interviews and observation. Data triangulation also used to analyze with relevant concepts, theories, and supported by previous research from various secondary sources (Moleong, 2004). Researchers in this case use judgmental sampling techniques to determine the appropriate source of information, in order to provide reliable information, and specifically carried out by relying on purposive sampling strategies and the type of criterion sampling (Michael Quin Patton, p.234).

Data analysis was processed qualitatively. Thematic methods are used in data analysis using empirical evidences to link the basic concepts that have been compiled in the research framework. Researchers use pre-existing theories as a reference to social contexts and organize data based on theories that have emerged previously through open coding (Neuman, 2003:451).

\section{FINDING \& DISSCUSSIONS}

\section{A. Community Relations as the Core Corporate Value}

Community relations that we know so far are only one type of relationship or public relations tools in implementing a company's Corporate Social Responsibility, apparently in the case of Saung Angklung Udjo (SAU) is much different in terms of its application. Community relations is not only seen as a type of relationship or a communication strategy that must be owned by a company.

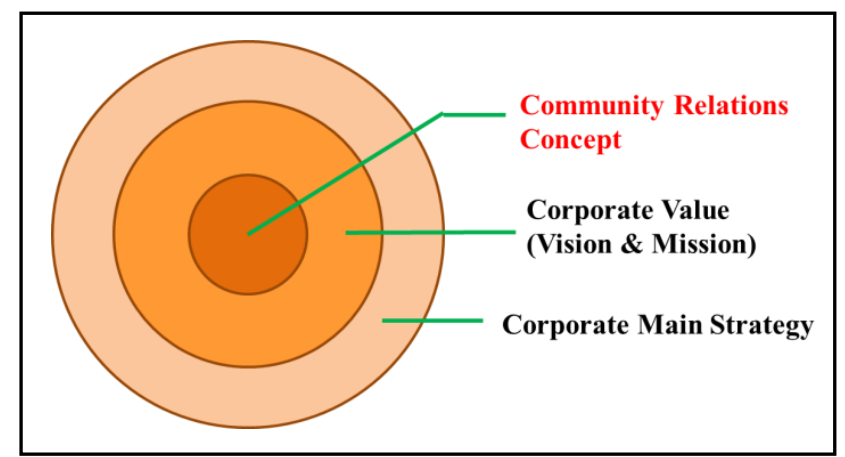

Fig. 1. Scheme how community realtions concept be the core of corporate value and be the basis to all bussiness strategies

In the case of SAU, community relations was developed to be a value that was adopted from the beginning of SAU. The concept of community relations has been included as the basic foundation of the company which was implemented in the main strategies of the whole SAU business line as seen in Fig. 1. This is in line with what Primahendra (2011: 97) said that Corporate Social Responsibility (CSR) that was designed from the beginning and developed along with social dynamics will has a multiplier effect rather than CSR which is developed as an negative response or demand from society. It would be far more effective, if the company had identified the potential negative impacts from the beginning and integrated them into the CSR program which was implemented as early as possible when the problems had not yet occurred.

The synthesis that researchers can take from this section is community relations as a form of CSR should be a company value and planned from the beginning, so it is not a reactive action, but a proactive action that will have a greater impact for both parties, which are company and society. The community relations program should not only be a repressive strategy for overcoming negative impacts experienced by the community due to company actions. If this has happened, of course the impact of the community relations program will only last in the short term. Moreover, if a company has allocated a large amount of funds for the short term CSR program, these companies will feel disappointed because the result or impact of the program will not significantly beneficial to the company. CSR not always talks about cost, but about company policy. CSR can still be implemented without having to spend a large budget, but it is more effective if CSR is part of the company, starting from the management process, company management, utilization of local resources, production processes that are safe, efficient and do not pollute the environment [4]. As has been done by SAU, where CSR is implemented in all company activities, it even becomes a breath or value that must be used by the company, starting from the management of the company, production, manufacture, performance, marketing, and so on.

There are many debatable arguments about the pros and cons that companies should not expect the benefit from the community relations program. Even though, the case of SAU above clearly shows the benefits for the company, which business and social impact could go hand in hand. As stated in the Triple Bottom Line theory or 3P, namely People, Planet, and Profit become inseparable entities in discussing 
CSR as a form of implementing the concept of community relations.

First, people means the community, both those around the company and employees within the company. They are the most important stakeholders for the company, because the support of the surrounding community is needed for the sustainability and development of a company. The company needs to be committed to strive to provide maximum benefits to the community which are implemented in various forms of care, thereby improving the quality of life of the community.

Second, the planet, which is the natural environment as something related to all fields of human life. Like the law of causality, if we take care of the environment, the environment will also benefit us.

Third, profit, related to welfare or economic prosperity to ensure the survival of the company. This finding is also in accordance with what was stated by Rogovsky [5] by quoting the concept of Transformed Corporate Community Relations from Barbara W. Altman, showing organizations that carry out CSR with an approach as a value and strategy, proved to be able to drive employee's engagement and satisfaction. This research convince that corporate success can only be achieved if the surrounding community prosperous as well.

\section{B. Implementation of Community Relations as the Main Business Strategy in order to make Positive Corporate Reputation \& Sustainablity}

Following the previous discussion on understanding how the concept of community relations is internalized into a value shared by the company, this section will discuss the implementation of the strategy in the form of activities or programs carried out by Saung Angklung Udjo to related stakeholders and finally we will see the benefits obtained by these stakeholders also the company.

The first stakeholder is the employee as an important part of the operation of the company. Employee is people who work in the SAU's office formally and have functional positions in the company's structure, from low level staff to president directors. Based on the findings of the researcher, half of the employee came from people who live around the company. [6]

The second stakeholder is the surrounding people who live nearby the company and closely related to the company's business, such as angklung craftsmen, souvenir suppliers, traditional food and beverage suppliers, and children as performers at SAU shows, as seen in Fig. 2.

Third stakeholder is bamboo farmers as SAU's fostered partner (mitra binaan SAU). Although not from local residents, bamboo farmers who are located in several places around West Java, such as Garut \& Tasikmalaya, also be the focus of the researcher, because without a good relationship with them, the company will find it very difficult to get good quality bamboo suppliers according to company standards with reasonable price.

The fourth stakeholder is the non-profit organizations and the private sector in tourism industry. They are parties who are not in the environment around SAU, but cover a wider area, both inside and outside the city of Bandung. These stakeholders are considered as related stakeholders and also supported the success of SAU's business, such as travel agents, hotels, cultural and youth communities.

Last but not least, the important stakeholder of SAU is government agencies, both at regional and national level. This stakeholder also included with educational institutions, both basic education (SD/MI), secondary (SMP/MTS, SMA/SMK/MA), and higher education institutions.

This research tries to compile all community relations programs mainly done since decades ago from PT SAU to every related stakeholders and also the advantages that is received by both parties as seen in Table 1 .

TABLE I. COMMUNITY RELATIONS PROGRAMS OF PT SAUNG ANGKLUNG UDJO TO ALL STAKEHOLDERS

\begin{tabular}{|c|c|}
\hline No. & Community Relations Programs of PT Saung Angklung Udjo \\
\hline \multirow[b]{2}{*}{1} & Stakeholder: Employee of PT SAU \\
\hline & $\begin{array}{l}\text { Community relations programs: } \\
\text { - Hold breakfast \& coffee morning between employees for sharing } \\
\text { session about knowledge, problems, solutions, ideas or } \\
\text { improvement of the company, every week from lowest level to } \\
\text { the top level (using the paternalistic approach) } \\
\text { - Hold a Al-Qur'an Recitaion, Joint Iftar (Buka Puasa Bersama) in } \\
\text { ramadhan month every year } \\
\text { - Hold a Talent \& Self-Development Training, Family Gathering } \\
\text { or Company Outing once a year } \\
\text { - Volunteering of the employee for company social events }\end{array}$ \\
\hline \multirow[b]{2}{*}{2} & $\begin{array}{l}\text { Stakeholder: Bamboo Farmers (located accross West java area, } \\
\text { such as Ciamis, Garut, Tasikmalaya, Majalengka, Bandung Barat, } \\
\text { Banten, Bandung, Surade, Cirebon, Bogor, etc.) }\end{array}$ \\
\hline & $\begin{array}{l}\text { Community relations programs: Development of skill and } \\
\text { knowledge of bamboo farmers through long-term training program } \\
\text { about the cultivation of bamboo with high quality standards in } \\
\text { order to maintain the quality of bamboo as a raw material for } \\
\text { making great quality of angklung. }\end{array}$ \\
\hline \multirow[b]{2}{*}{3} & $\begin{array}{l}\text { Stakeholder: Angklung Craftsman, Souvenir \& Traditional Snack } \\
\text { Suppliers (people who live around the company - surrounding } \\
\text { commmunites) }\end{array}$ \\
\hline & $\begin{array}{l}\text { Community relations programs: } \\
\text { - Hold workshop and training for long term period on the process } \\
\text { and mechanism of making high quality angklung with home } \\
\text { industry system and a "network of friendship" between angklung } \\
\text { craftsmen for SAU. } \\
\text { - Hold workshop and training for long term period in the } \\
\text { manufacture of traditional drink, foods \& snack, also training in } \\
\text { making crafts/ souvenirs/ merchandise for the shop } \\
\text { - Coaching session on financial management. } \\
\text { - Hold a Al-Qur'an Recitaion, Joint Iftar (Buka Puasa Bersama) in } \\
\text { ramadhan month every year } \\
\text { - Providing insurance in health, accident, disaster, etc. for those in } \\
\text { need }\end{array}$ \\
\hline \multirow[b]{2}{*}{4} & $\begin{array}{l}\text { Stakeholder: Children \& Teenagers Performers (people who live } \\
\text { around the company - surrounding commmunites) }\end{array}$ \\
\hline & $\begin{array}{l}\text { Community relations programs: } \\
\text { - Hold a SAU Talent Scouting which focusing on training } \\
\text { regularly for the children in talent, soft skills, leadership, self- } \\
\text { development, and also Sundanese traditional arts, playing music, } \\
\text { dancing, singing, public speaking, english proficiency, etc. } \\
\text { - Provide academics assistance or tutoring after school regularly } \\
\text { with 'learning while playing' approach } \\
\text { - Provide scholarships for school fees for children who have } \\
\text { participated in regular performances of SAU and ranked well } \\
\text { academically at school } \\
\text { - Provide insurance in health, accident, disaster, etc. for those in } \\
\text { need }\end{array}$ \\
\hline
\end{tabular}




\begin{tabular}{|l|l|}
\hline \multirow{6}{*}{5} & Stakeholder: Youth Organization \& Private Sector Partnership \\
\cline { 2 - 2 } & Community relations programs: \\
- Hold gathering/ gala dinner regularly every 2 months between \\
parties who collaborate with SAU, such as travel agents, hotels, \\
vehicle rentals in order to socialize the new program of SAU and \\
maintaining good relationship \\
- Making collaboration with the Arts and Culture Community and \\
other youth communities by providing space at SAU for their \\
event without any charges. Making SAU as free communal \\
space for youth. \\
\hline Stakeholder: Government Agencies (National \& Regional level) \\
\& Educational Institutions \\
\hline $\begin{array}{l}\text { Community relations programs: } \\
\text { - Support the government in cultural missions and diplomacy } \\
\text { events inside \& outside Indonesia } \\
\text { - Collaboration with the Ministry of Foreign Affairs in cultural } \\
\text { exchange programs with foreign students to learn Indonesian } \\
\text { traditional arts, especially Sundanese culture at SAU with costs } \\
\text { fully funded by SAU for } 3 \text { months } \\
\text { - Support the government to provide angklung musical } \\
\text { instruments for elementary schools accros West Java and give } \\
\text { regular training to art teachers in West Java to study angklung } \\
\text { for } 3 \text { months for free. } \\
\text { - In collaboration with Ministry of Culture \& Education to hold a } \\
\text { SAU Academy to give Cultural Arts Scholarships to college } \\
\text { students and vocational high school (SMK) students to study at } \\
\text { SAU (followed by providing transportation, accommodation, } \\
\text { consumption, science, etc. for free) } \\
\text { - In Collaboration with the Indonesian College of Arts (Sekolah } \\
\text { Tinggi Seni Indonesia) in Bandung to create and manage a } \\
\text { traditional art laboratory and bamboo land for SAU in the } \\
\text { campus area for student to learn it. }\end{array}$ \\
\hline
\end{tabular}

Based on the above analysis, an explanation can be made that community relations are not just building good relations with the people around the company's operating location to get a 'social license' to operate. If that still happens, then the community relations which run by the company will benefit more for the company than the community. This kind of business practice, which views a good relationship with the community as a business strategy to reduce risk and maximize profits, is considered as traditional CSR formulation.[7]
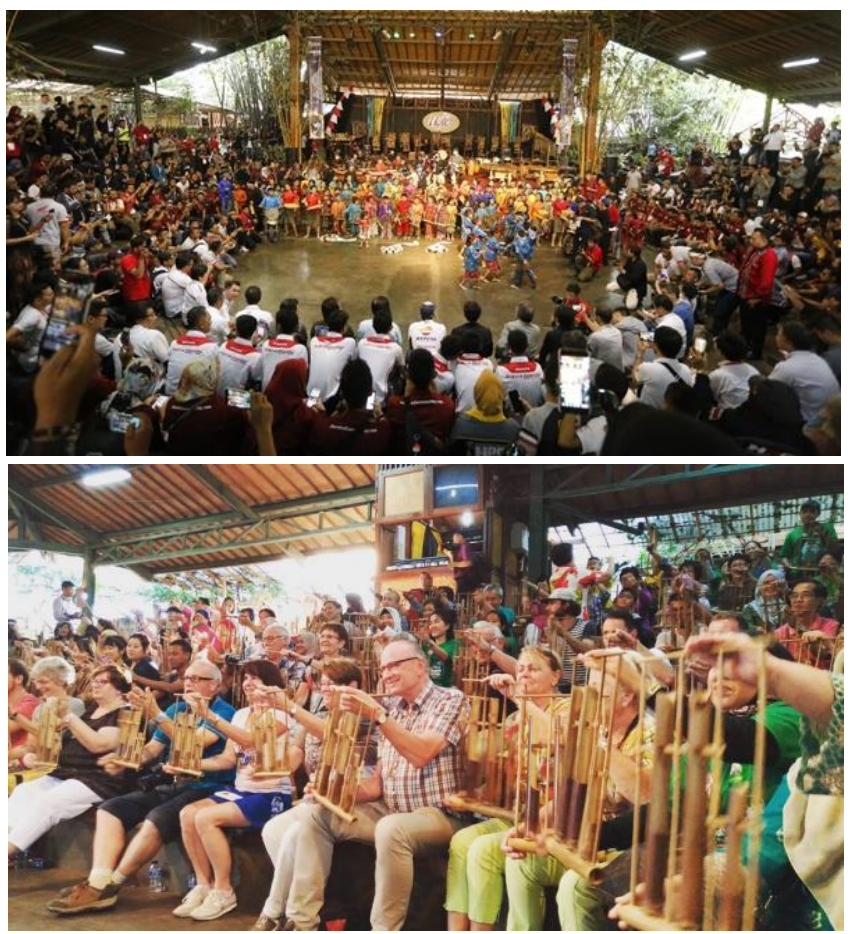

Fig. 2. Large number of visitors of Saung Angklung Udjo every day from local and foreign tourist

Business practices should be carried out by the company not just looking at social responsibility as a form of activity, but rather become the 'spirit' of the company that underlies all decision making process. Corporate social responsibility is integrated into day-to-day management, because the company realizes that its business practices must be carried out transparently so that people can assess the company's social and environmental performance. In Green Paper (2001:16) stated that corporate social responsibility is an integral part of the company's strategic planning and daily operational performance of the company. Establishing a good relationship with the surrounding environment is not enough just to run with philanthropic or short term activities. Moreover, it should build partnerships for mutual benefit.

The role that PR, can play in building this partnership is actually very major. emphasized that the role of public relations in maintaining the sustainability of business organizations is to focus on efforts to create mutual understanding, build good relations, unite people and institutions into harmony. Nowadays, when most business organizations write their annual reports based on the triple bottom line concept that includes (a) financial achievement of the company, (b) achievements in human resource development, and (c) achievements in the field of community and environment. 


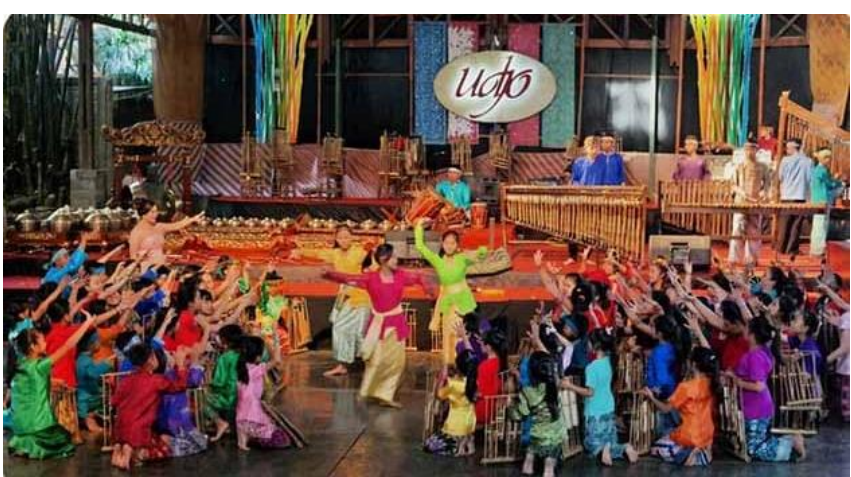

Fig. 3. Children performers of Saung Angklung Udjo

For business organizations, as confirmed by MacNamara, the aim of doing community relations is to maintain the sustainability of the company. However, the goal also for seeking a mutual benefit. Business organizations should not only seek for financial results or profits, but must also develop their human resources and carry out community activities to maintain sustainability. This partnership was developed so that business organizations see themselves not only as an economic engine that works for profit, but also see themselves as social institutions that can provide social benefits. Actually, CSR can be implemented without having to allocate a lot of budget. CSR can be more effective if it is part of the management process, and in line with business strategies and company goals. CSR designed from the beginning and developed in line with social dynamics will have a multiplier effect to all related stakeholders (Primahendra, 2011: 97).

Suhandari M. Putri in Untung (2008:7-8) said there are four category of companies in implementing CSR. The best category is green category, where companies have placed CSR as the core strategy and heart of their business, so CSR is not only considered as an obligation, but the necessity which will be used as social capital. [8]

SAU can be considered as the green category company [9], because community relations has been included as a major part of the company from the beginning. This is manifested in the company's vision and mission, so that it becomes the main objective of the company's business. Next, that value is derived to the main strategy that is applied to all SAU's stakeholders. This research also reaffirms the concept of community relations that the most important relevant stakeholders for the company are not only the people who live around the location where the company operates, but also all stakeholders who are also related and potential in giving impact to the company.

Looking at the analysis obtained and based on reputation indicators from Fombrun (1998), responsibility becomes a major factor that shapes SAU's reputation. The responsibility carried out by SAU turned out to trigger three other factors, such as trustworthiness, credibility, and reliability. When we talking about the reputation of the company, many experts said that financial performance as an indicator of reputation. But the findings in SAU were slightly different, the results of positive reputation in the eyes of the SAU's stakeholders were the determinant factors in improving company's financial performance. [10]
Few proofs of the success of SAU can be seen from the large number of visitors every day reaching approximately 1500 people both local and foreign tourists, as seen in Fig. 3. They also have more than 500 students who is ready to perform every day, as seen in Fig. 2. This stage of reputation is not something that can be obtained easily and in a short time. SAU has succeeded to gain the trust from both the surrounding community who depend their lives on SAU and also from various parties to be able to show something that has credibility. It is result that SAU got from the strategy focused on developing the community in their business from the beginning.

On the other hand, looking at the case of the development of CSR in Indonesia, there are still many organizations or companies that focus on internal companies and seek for benefit first, then carry out a CSR program as an obligation from the government or response to negative impact from the community. But unlike the case with SAU, they had made a vision that was socially responsible and prospering the community from the beginning, especially in preserving Sundanese arts and so on. This case became a very interesting phenomenon, because if there were no community relations activities, then their business would not exist either. This kind of approach is still rarely done in companies in Indonesia.[11]

However, it can be said that community relations as a form of implementation of corporate social responsibility which so far has the stigma of not being able to give tangible returns, is not applied in the case of PT Saung Angklung Udjo. Community relations programs clearly give benefit of positive corporate reputation which leads to financial improvement which is the result of 'long-term investment'. SAU case has proved that reputation can be a strategic resource for a company that can affect its financial performance (Deephouse, 2002).

In addition, based on the elaboration of theories and concepts in part 2, the results of the analysis found new findings, in terms of modifying theoretical framework implementation of CSR in Indonesia. Further results found by researchers in the field illustrate that the reputation increases financial performance which results in corporate sustainability.

\section{CONCLUSION}

Based on the research objectives, community relations is clearly implemented to be the main value by the Saung Angklung Udjo (SAU) since the beginning they established, thereafter the community relations is implemented as the main strategy in the whole of SAU's businesses line. Based on the analysis of researcher, the implementation of the strategy is clearly seen in different programs or activities according to the related stakeholders. As a result, those programs have provided real benefits to all the related stakeholders effectively, especially in the context of preserving angklung as cultural heritage. The SAU phenomenon explains clearly that community relations strategy which an implementation of CSR is not only a supporting strategy, but also can be the main strategy. Besides, the community relations which always considered only as an obligation and not beneficial for the company, does not apply to the case of SAU, where community relations clearly build a positive corporate reputation that 
leads to increase of financial side. Eventually, it provides long-term investment that makes traditional culture-based company like SAU sustainable more than 53 years until now.

\section{REFERENCES}

[1] A. Makaros and T. Zehavi, "Corporate Social Responsibility to the Community: A Process-oriented Model for Contractual Relations," Community Dev., vol. 39, no. 4, pp. 40-50, 2008, doi: $10.1080 / 15575330809489657$.

[2] G. Palazzo and U. Richter, "CSR business as usual? the case of the tobacco industry," J. Bus. Ethics, vol. 61, no. 4, pp. 387-401, 2005, doi: 10.1007/s10551-005-7444-3.

[3] R. De Carvalho, "Reputation Management As Relationship," Methodology, no. July, pp. 1-11, 2004.

[4] D. Prayoga, T. S. Rachmawati, and E. Rosfiantika, "eJurnal Mahasiswa Universitas Padjadjaran Vol.1., No.1 (2012)," Peran Website bapusipda.jabarprov.go.id Sebagai Media Promosi Badan Perpust. dan Kearsipan Drh. Provinsi Jawa Barat, vol. 1, no. 1, pp. $1-10,2012$.

[5] G. A. Yudarwati, "Bentuk Tanggung Jawab Sosial Organisasi," Ilmu Komun., vol. 1, no. 2, pp. 143-156, 2004, [Online]. Available: http://ojs.uajy.ac.id/index.php/jik/article/view/164.

[6] M. Nasir and G. F. Qurani, "Pengaruh Penerapan Corporate Social Responsibility terhadap Persepsi Nasabah Bank dan Dampaknya terhadap Corporate Image," The Winners, vol. 12, no. 2, p. 180, 2011, doi: $10.21512 / \mathrm{tw} . v 12 \mathrm{i} 2.675$

[7] K. Ruck and S. Trainor, "Developing Internal Communication Practice That Supports Employee Engagement," Public Relations Commun. Manag. State Prof., pp. 138-148, 2012, doi: http://dx.doi.org/10.1186/1472-6963-12-97.

[8] A. C. Milyartini, R dan Alwasilah, "Saung angklung udjo sebuah model transformasi nilai budaya melalui pembinaan seni untuk pembangunan ketahanan budaya," J. Integritas, pp. 1-28, 2012, [Online].

Available: http://file.upi.edu/Direktori/FPSD/JUR._PEND._SENI_MUSIK/1317 60819.

[9] D. Sukmana, "Konsep Pemberdayaan Masyarakat Melalui Pengembangan Komunitas Berbasis Potensi Lokal (Studi Di Desa Wisata Bunga Sidomulyo, Kota Batu-Jawa Timur)," J. Humanit., vol. 6, no. 1, p. 11536, 2010.

[10] S. Bruhn-Hansen, "Corporate Social Responsibility-A case study of Starbucks' CSR communication through its corporate website," Pure.Au.Dk, pp. 1-42, 2012, [Online]. Available: http://pure.au.dk/portal/files/45282206/BA_Thesis.pdf.

[11] S. Martina et al., "Sri Martina Intan Permatasari Hassan, 2013 Pengaruh Customer Value Dalam Meningkatkan Kepuasan Wisatawan Di Saung Angklung Udjo (Survei terhadap Wisatawan Nusantara Individu di Saung Angklung Udjo) Universitas Pendidikan Indonesia | repository.upi.edu | p," pp. 1-17. 